\title{
Erratum to: The dissolved organic matter as a potential soil quality indicator in arable soils of Hungary
}

Tibor Filep • Eszter Draskovits • József Szabó • Sándor Koós • Péter László • Zoltán Szalai

Published online: 10 March 2016

(C) Springer International Publishing Switzerland 2016

Erratum to: Environ Monit Assess (July 2015) 187, Issue $7: 479$

DOI: 10.1007/s10661-015-4700-6

In the published version of this article unfortunately contained an error in the affiliation section.

The affiliations of Zoltán Szalai should have been Research Centre for Astronomy and Earth Sciences, Budapest, Hungary and Faculty of Science, Eötvös Loránd University, Budapest, Hungary.

The corrected affiliations are shown below.

The online version of the original article can be found at http://dx. doi.org/10.1007/s10661-015-4700-6.

T. Filep $(\bowtie) \cdot$ E. Draskovits · J. Szabó • S. Koós · P. László Research Institute for Soil Science and Agricultural Chemistry, Budapest, Hungary

e-mail: filept@rissac.hu

Z. Szalai

Research Centre for Astronomy and Earth Sciences, Budapest, Hungary

Z. Szalai

Faculty of Science, Eötvös Loránd University, Budapest, Hungary 